\title{
Geomorphic response runoff model for prediction of June monthly runoff from small watersheds
}

SANDIP NIKAM AND PRAVIN DAHIPHALE

Received : 06.01.2016; Revised : 13.02.2016; Accepted : 08.03.2016

See end of the Paper for authors' affiliation

Correspondence to :

\section{SANDIP NIKAM}

Agricultural Engineering Department, College of Agriculture, DHULE (M.S.) INDIA Email : spnikam74@gmail.com
-ABSTRACT : Quantitative assessment of runoff is needed for proper management of land and water resources especially for optimum agriculture production. This requires comprehensive knowledge of the various hydrological phenomena occurring in the catchment. All the watersheds cannot be gauged, as it would be costly and time consuming. Therefore, the indirect method of runoff quantification has to be resorted. The geomorphic parameters are quite useful as they reflect all the causative factors of the runoff. In the present study ten watersheds from Tapi catchment, Maharashtra, India were selected for development of geomorphic response models for prediction of June monthly runoff. Twelve geomorphic parameters were selected for development of model out of which two parameters, $\mathrm{Sa}$ and $\mathrm{Rb}$ are screened out in the principal component analysis. Remaining ten parameters are grouped into three physically significant components. The data sets were used to regress the runoff factor, $\mathrm{R} / \sqrt{\mathrm{A}}$, on three independent parameters (one each from already established components and rainfall factor, $\mathrm{P} / \sqrt{\mathrm{A}}$. It is observed that percentage deviation ranged from 0.3 to 7.0 using monthly runoff model for June. Therefore, developed runoff can be conveniently used for prediction of June month runoff from unguaged watersheds of the basin having similar physiographic conditions.

- KEY WORDS : Geomorphic response model, Geomorphological parameters, Runoff, Sediment production rate, $\mathrm{PCA}$

— HOW TO CITE THIS PAPER : Nikam, Sandip and Dahiphale, Pravin (2016). Geomorphic response runoff model for prediction of June monthly runoff from small watersheds. Internat. J. Agric. Engg., 9(1) :27-31. 